\title{
The antioxidant, antimicrobial, and clinical effects with elemental contents of pomegranate (Punica granatum) peel extracts: A review
}

\author{
Abdul Qahir ${ }^{1,2}$, Attiq-Ur-Rehman Kakar ${ }^{1}$ (D), Naqeebullah Khan ${ }^{1}$, Samiullah $^{1}$, Abdul Hakeem ${ }^{1}$, \\ Rehana Kamal $^{3}$ and Fazal-Ur-Rehman ${ }^{4}$ \\ ${ }^{1}$ Higher and Technical Education Department, Balochistan, Quetta 87300, Pakistan \\ ${ }^{2}$ Department of Chemistry, Faculty of Basic Sciences, University of Balochistan, Quetta 87300, Pakistan \\ ${ }^{3}$ Department of Obstetrics and Gynecology,, Bolan University of Medical and Health Sciences, Quetta 87300, Pakistan \\ ${ }^{4}$ Department of Microbiology, Faculty of Life Sciences, University of Balochistan, Quetta 87300, Pakistan
}

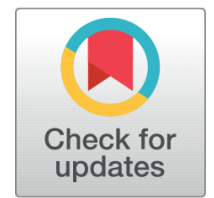

Received 12-12-2020

Revised 15-12-2020

Accepted 01-03-2021

Published 08-03-2021

\section{Corresponding Author}

Attiq-Ur-Rehman Kakar

Department of Chemistry, Faculty of Basic Sciences, University of Balochistan, Quetta 87300,

Pakistan

DOI https://doi.org/10.47419/ bjbabs.v2i01.33

Pages: 21-28

Distributed under the terms of the Creative Commons

Attribution-NonCommercial 4.0 International (CC-BY-NC 4.0), which permits use for any non-commercial purpose, distribution, and reproduction in any medium, provided that the original work is properly cited.

Copyright: (c) 2021 Abdul Qahir, Attiq-Ur-Rehman Kakar, Naqeebullah Khan, Samiullah, Abdul Hakeem, Rehana Kamal, Fazal-Ur-Rehman

\section{OPEN ACCESS}

\section{ABSTRACT}

Pomegranate belongs to the family of Punicaceae. It has deciduous shrubs. Pomegranate is generally cultivated in Afghanistan, China, Iran, India, Pakistan, and USA. This study aimed to review the pomegranate peels for exploring their importance in the field of health. This review showed that pomegranate is used as food and plays a vital role in the medicinal field. Because pomegranate fruit and its peel extraction contain various compounds like antioxidants, phenolic Acid, Flavonoids, Tannins etc., that have been found very effective in the health field. Due to the presence of antioxidants and other active compounds, pomegranates' peel is imperative for the betterment of human health. Besides, various medicines such as antidiarrheal medicine may be prepared from the peel extract of pomegranate. Peel extract can act against various microbes such as Klebsiella pneumonia and Staphylococcus epidermidis, Bacillus subtilis, Klebsiella pneumoniae, Salmonella typhi, E. coli, S. aureus etc. The pomegranate strip and root remove have been accounted for in creatures to diminish blood glucose activity. It concludes that further research is needed to explore the hidden characteristics of pomegranate peel.

Keywords antimicrobial activity, antioxidant, clinical activity, peel, pomegranate

\section{INTRODUCTION}

Pomegranate is a kind of fruit that is used as food staff and for juice purposes. It has many benefits for the health of the human being. The juice of Pomegranate is rich in phenolic contents, antioxidants etc. These antioxidants play a vital role in controlling many diseases. Besides, pomegranate juice is also rich in biochemical phytonutrients, which may help solve many health problems. ${ }^{1}$ 
Pomegranate belongs to the family of Punicaceae. It has deciduous shrubs. Pomegranate is generally cultivated in Afghanistan, China, Iran, India, Pakistan, USA. ${ }^{2}$ The fruit of pomegranate plays a vital role in the health of human beings. Antioxidants and bioactive phenolic contents have been reported in the fruits of pomegranates that are imperative for better human health. The compounds that are useful for human health are present in the fruit and juice of pomegranate and present in greater quantity in the peel of pomegranate. Therefore, pomegranate plays the role of a medicinal plant. ${ }^{3}$

The peel of fruits contains bioactive compounds and are very beneficial economically in industries of food processing. Researchers are interested in searching for beneficial phytochemicals in the peels of fruit and using them in various cosmetic and pharmaceutical industries for humankind's welfare. Among the fruits, the peel of pomegranate has a high number of phytochemicals. The peels of pomegranate attracted researchers' attention towards themselves and have greater significance in the field of medicine and nutrition. ${ }^{4}$ The compounds present in the peels have different groups such as phenolic acid, flavonoids, tannins, etc.

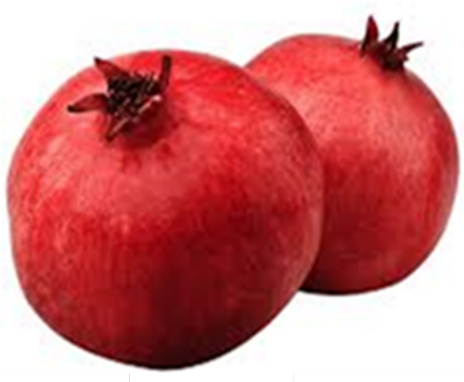

A

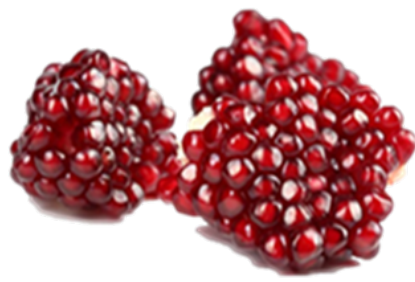

B

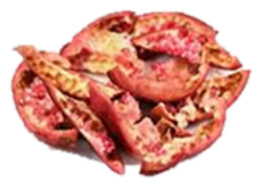

C

Figure 1 A) Whole pomegranate B) pomegranate fruit and C) pomegranate peel.

\section{ANTIOXIDANTS IN POMEGRANATE AND ITS PEEL}

Peel of pomegranate is a useful source of bio-activated tannins (ellaganitans, gallotannins, gallagyl esters), flavonoid, and phenolic acids (hydroxycinnamic and hydroxybenzoic acids). Akhtar et al., ${ }^{3}$ Amri et al., ${ }^{5}$ and Gadže et al. ${ }^{6}$ recorded a higher degree of peel of pomegranate in methanol extracts of pomegranate peel, herb, seed and leaf than the other compounds and contrasted total phenolic, flavonoid, anthocyanin and hydrolyzable tannin. 
In the acetone extract, the highest values of phenolics, flavonoids, tannins and anthocyanins were recorded in the water, ethanol and acetone extracts, which included four Tunisian pomegranate peels ("Acide," "Gabsi," "Nebli" and "Tounsi" ecosystems). ${ }^{7}$ South African pomegranate cultivar pomegranate pulp extract ( $\mathrm{PoPx}$ ) was established and measured for pompous cyanines (delphinidine 3,5-diglucoside and cyanidine 3,5-diglucoside), flavonoid (catechine, epicatechin and rutin) and hydrolyzable tannin (ellagic acid, and hydroxybenzoic acid: gallic acid). ${ }^{8}$

Several researchers in separate parts of the world have been utilizing numerous analytical methods to extract plant leaves. Yasoubi and his collaborators used two techniques to extract phenolic compounds from grenade peels. ${ }^{9}$ In combination with the Folin-Ciocalteu reagent, complete phenolic compounds were determined with normal tannic acid. The peel extract is moderately potent in antioxidants and should be called a rich natural source of antioxidants.

The pomegranate peel extraction research study was carried out by Gadže et al. ${ }^{6}$ Pomegranate is a product high in nutrient-rich antioxidant plant compounds. Based on peels, nuts, sheets and berries, all polyphenols were hydrolyzable, and flavonoids were counted. They documented a high level of radical free action in skin and flowers. The findings showed that extraction processes would yield high anti-oxidation and an extremely beneficial antioxidant effect for commercial pomegranates.

Ferrazzano and his colleagues ${ }^{10}$ carried out a theoretical analysis of grenade peelings. They treated this fruit as the primary source of the beneficial health effect of pomegranate as an exceptional antioxidant action. The growing attention is given to grenades also culminated in a rise in the amount of pomegranate-producing countries. These data may be helpful while the pomegranate industries discover and cultivate new cultivars.

This work contained four Turkish explosives. They identified complete phenolic compounds by using the Folin - Ciocalteu colorimetric test. 'Lefan' indicates that the highest amount of total phenolic content exhibited has been evaluated by the four common cultivars. ${ }^{11}$

Pomegranate juice and peels were important in phenolic compounds with antioxidant activity. Door skin has been found to show 58 per cent of the other two skins' strongest antioxidant activity. In this trial, also, the high antioxidant ability of pomegranate for natural food preservatives is reported. ${ }^{12}$

\section{ANTIMICROBIAL ACTIVITY OF POMEGRANATE PEEL}

The application of pomegranate peels is very effective to control various microbes. Several research studies have indicated that pomegranate peels are effective against Klebsiella pneumonia and Staphylococcus epidermidis as antimicrobial activity. ${ }^{13}$

Prashanath and his coworkers have examined the peels of pomegranate for antimicrobial activity. They concluded that the pomegranate peels contain many such active compounds that control microbial activities. These can be effective against microbes like Bacillus subtilis, 
Klebsiella pneumoniae, Salmonella typhi, E. coli, S. aureus, etc. ${ }^{14}$ While on other hand, an investigation on the peels of pomegranate by Braga and colleagues has also shown that it can control the production of enterotoxin. ${ }^{15}$

The research study of Alan and coworkers indicated that the pomegranate extract has greater antimicrobial properties against Shigella spp. than chloramphenicol but less than trimethoprim. ${ }^{16}$ The extraction of the peels of pomegranate is highly susceptible to the Shigella sunni. Mc Carrell and colleagues' analysis exhibited antimicrobial activities of the peels extract of pomegranate to B. subtilis NCTC 6452 and S. aureus NCTC 6571. ${ }^{17}$ The extract of pomegranate peels has also been reported effective against the infection caused by Candida albicans. ${ }^{18}$ It is also helpful for preventing various microbes such as E. coli, S. aureus, Y. enterocolitica, C. albicans. It can also control the growth of the human influenza virus $\mathrm{H}_{3} \mathrm{~N}_{2}$.

Kanatt and his colleague also reported that the peel extract of pomegranate contains active compounds that can show antimicrobial activity. They also indicated that it had reducing power and can also form a chelation of iron. It was observed very high at $1 \mathrm{mg} / \mathrm{ml}$. The study also revealed that the peel extract of pomegranate was outstanding in superoxide anion radical and hydroxyl radical scavenging. ${ }^{19}$

\section{CLINICAL APPLICATIONS OF POMEGRANATE EXTRACTS}

Pomegranate peel is a common treatment for diarrhoea and constipative effect. The antidiarrheal effect is dose-dependent and water intake dependent. Antidiarrheal medicine might be prepared from pomegranate peel in the future. ${ }^{17}$ The fruit of pomegranate act as an anti-parasite for living organisms.

The pomegranate oil obtained will completely prevent prostaglandin or leukotriene creation by inhibiting cyclooxygenase and lipoxygenase enzymes, boosting the utilization of oils or their derivatives internal or external anti-inflammatory materials. ${ }^{20}$

The pomegranate strip and root remove have been accounted for in creatures to diminish blood glucose activity. ${ }^{21} \mathrm{~A}$ few specialists have zeroed in on the pomegranate strip to recognize various phenomenal impacts of this plant on human wellbeing. Pomegranate strip has a high antimicrobial and cell reinforcement limit, making it a strong source of regular antimicrobial and cancer prevention agent factors. ${ }^{22,23}$ The polyphenols have demonstrated wellbeing advancement and sickness counteraction impacts. In such a manner, free revolutionaries have been engaged with the aetiology of a wide assortment of significant sicknesses, for example, malignant growth, Parkinson's illness, joint pain, Alzheimer's disease, Human Immunodeficiency viral disease (HIV), and diabetic inconveniences. ${ }^{24}$

\section{ELEMENTS IN POMEGRANATE}


Muhammad Rahim et al. ${ }^{25}$ reported heavy metals like $\mathrm{Cr}, \mathrm{Co}, \mathrm{Ni}, \mathrm{Cd}$ and $\mathrm{Pb}$ in pomegranate, Khyber Pakhtunkhwa, Pakistan. The average concentration was 0.0750 $\mathrm{mg} / \mathrm{kg}, 0.0095 \mathrm{mg} / \mathrm{kg}, 0.0538 \mathrm{mg} / \mathrm{kg}, 0.0083 \mathrm{mg} / \mathrm{kg}$ and $0.0830 \mathrm{mg} / \mathrm{kg}$ respectively. The overall result was below the WHO permissible limit. Other study conducted in India on heavy metals in pomegranate indicated $22.4 \mu \mathrm{g} / \mathrm{g}$ of $\mathrm{Cr}, 82.2 \mu \mathrm{g} / \mathrm{g}$ of $\mathrm{Cu}$ while $\mathrm{Cd}$ indicated as absent. ${ }^{26}$ The levels of both $\mathrm{Cr}$ and $\mathrm{Cu}$ has crossed the permissible limit $(2.3 \mu \mathrm{g} / \mathrm{g})$ and $(40 \mu \mathrm{g} / \mathrm{g})$, respectively, given by WHO. A research study conducted in Iraq reported $100 \mathrm{ppm}$ of $\mathrm{Cr}, 57 \mathrm{ppm}$ of $\mathrm{Cu}, 28 \mathrm{ppm}$ of $\mathrm{Pb}$ and $0.12 \mathrm{ppm}$ of $\mathrm{Cd} .{ }^{27}$ Chromium was reported to be in the range of permissible limit of WHO/FAO (1984). ${ }^{28}$ The lead source is fuel incinerator, solid industries waste. If this lead is inhaled, it is mixed with blood and decrease the haemoglobin in the blood. Also, lead may cause kidney, immune problems etc. even it can become the cause of comma increment and death. ${ }^{29}$ At the same time, the source of copper is the dissolved salts of copper. It is very toxic and seriously influences respiratory system. ${ }^{30}$

\section{CONCLUSIONS}

Pomegranate is a type of fruit that contain various factors which can act against different diseases. An interest in the various remedial properties of $P$. granatum in the last decade has prompted various in vitro, creature, and clinical preliminaries. Pomegranate is a powerful cancer prevention agent, better than red wine and equivalent to or better than green tea. Likewise, anti-carcinogenic calming properties recommend its possible use as a treatment or extra for avoiding and treating a few sorts of malignant growth and cardiovascular sickness. Because of pomegranate's antimicrobial properties, it might help in the prevention of contamination by dental microbes, pathogenic E. coli O157:H7, and Vague-like MRSA.

\section{ACKNOWLEDGEMENTS}

The authors are glad to say thanks to the Department of Chemistry, University of Balochistan Quetta and Department of Obstetrics and Gynecology, Bolan University of Medical and Health Sciences, Quetta Pakistan for providing all facilities and other support.

\section{DECLARATIONS}

\section{Authors' contributions}

All authors have equally contributed to this work.

\section{Conflicts of interest}

None. 


\section{Ethical approvals}

Not required for reviews.

\section{Data availability}

Not applicable.

\section{Funding resources}

None.

\section{REFERENCES}

1. Tang F. Metabolic profiling of complex mixtures using novel NMR-based approaches and chemometrics: Pomegranate juice as a case study. The Ohio State University; 2020. Doctoral dissertation.

2. Kahramanoglu I, Usanmaz S. Pomegranate Production and Marketing. CRC Press; 2016.

3. Akhtar S, Ismail T, Fraternale D, Sestili P. Pomegranate peel and peel extracts: Chemistry and food features. Food Chem. 2015;174:417-425. Available from: 10.1016/j.foodchem.2014.11.035.

4. Singh B, Singh JP, Kaur A, Singh N. Phenolic composition and antioxidant potential of grain legume seeds: A review. Food Res Int. 2017;101:1-16. Available from: 10. 1016/j.foodres.2017.09.026.

5. Amri Z, Zaouay F, Lazreg-Aref H, Soltana H, Mneri A, Mars M, et al. Phytochemical content, Fatty acids composition and antioxidant potential of different pomegranate parts: Comparison between edible and non edible varieties grown in Tunisia. Int J Biol Macromol. 2017;104:274-280. Available from: 10.1016/j.ijbiomac.2017.06.022.

6. Gadže J, Voća S, Čmelik Z, Mustać I, Ercisli S, Radunić M. Physico-chemical characteristics of main pomegranate (Punica granatum L.) cultivars grown in Dalmatia region of Croatia. Journal of Applied Botany and Food Quality. 2013;85(2):202.

7. Abid M, Yaich H, Cheikhrouhou S, Khemakhem I, Bouaziz M, Attia H, et al. Antioxidant properties and phenolic profile characterization by LC-MS/MS of selected Tunisian pomegranate peels. J Food Sci Tech. 2017;54(9):2890-2901. Available from: 10.1007/s13197-017-2727-0.

8. Fawole OA, Makunga NP, Opara UL. antioxidant and tyrosinase-inhibition activities of pomegranate fruit peel methanolic extract. BMC Complement Altern Med. 2012;12:200. Available from: 10.1186/1472-6882-12-200.

9. Yasoubi P, Barzegar M, Ma S, Azizi MH. Total phenolic contents and antioxidant activity of Pomegranate (Punica granatum L.) peel extracts. J Agri Sci Tech. 2007;9(1):34-42.

10. Ferrazzano GF, Scioscia E, Sateriale D, Pastore G, Colicchio R, Pagliuca C, et al. In vitro antibacterial activity of pomegranate juice and peel extracts on cariogenic bacteria. BioMed Res Int. 2017;2017:2152749. Available from: 10.1155/2017/2152749. 
11. Gözlekçi S, Saraçoglu O, Onursal E, Özgen M. Total phenolic distribution of juice, peel, and seed extracts of four pomegranate cultivars. Pharmacogn Mag. 2011;7(26):161. Available from: 10.4103/0973-1296.80681.

12. Derakhshan Z, Ferrante M, Tadi M, Ansari F, Heydari A, Hosseini MS, et al. Antioxidant activity and total phenolic content of ethanolic extract of pomegranate peels, juice and seeds. Food Chem Toxicol. 2018;114:108-111. Available from: 10.1016/j. fct.2018.02.023.

13. Wise R, Hart T, Cars O, Streulens M, Helmuth R, Huovinen P, et al. Antimicrobial resistance. BMJ. 1998;317(7159):609-610. Available from: 10.1136/bmj.317.7159. 609.

14. Prashanth D, Asha MK, Amit A. Antibacterial activity of Punica granatum. Fitoterapia. 2001;72(2):171-173. Available from: 10.1016/s0367-326x(00)00270-7.

15. Braga LC, Shupp JW, Cummings C, Jett M, Takahashi JA, Carmo LS, et al. Pomegranate extract inhibits Staphylococcus aureus growth and subsequent enterotoxin production. J Ethnopharmacol. 2005;96(1-2):335-339. Available from: 10. 1016/j.jep.2004.08.034.

16. Alanís AD, Calzada F, Cervantes JA, Torres J, Ceballos GM. Antibacterial properties of some plants used in Mexican traditional medicine for the treatment of gastrointestinal disorders. J Ethnopharmacol. 2005;100(1-2):153-157. Available from: 10.1016/j.jep.2005.02.022.

17. McCarrell EM, Gould SW, Fielder MD, Kelly AF, Sankary WE, Naughton DP. Antimicrobial activities of pomegranate rind extracts: enhancement by addition of metal salts and vitamin C. BMC Complemen Altern Med. 2008;8(1):64. Available from: 10.1186/1472-6882-8-64.

18. Endo EH, Ueda-Nakamura T, Nakamura CV, Filho BPD. Activity of spraydried microparticles containing pomegranate peel extract against Candida albicans. Molecules. 2012;17(9):10094-10107. Available from: 10.3390/molecules170910094.

19. Kanatt SR, Chander R, Sharma A. Antioxidant and antimicrobial activity of pomegranate peel extract improves the shelf life of chicken products. Int J Food Sci Tech. 2016;45:216-222. Available from: 10.1111/j.1365-2621.2009.02124.x.

20. Devasagayam TP, Tilak JC, Boloor KK, Sane KS, Ghaskadbi SS, Lele RD. Free radicals and antioxidants in human health: current status and future prospects. J Assoc Physicians India. 2004;52:794-804. PMID: 15909857.

21. Jelodar G, Mohsen M, Shahram S. Effect of walnut leaf, coriander and pomegranate on blood glucose and histopathology of pancreas of alloxan induced diabetic rats. Afr J Tradit Complement Altern Med. 2008;4(3):299-305. Available from: 10.4314/ ajtcam.v4i3.31223.

22. Howell AB, D'Souza DH. The pomegranate: Effects on bacteria and viruses that influence human health. Evid Based Complement Alternat Med. 2013;2013(606212):1-11. Available from: 10.1155/2013/606212.

23. Viuda-Martos M, Fernández-López J, Pérez-Álvarez JA. Pomegranate and its many functional components as related to human health: A review. Compr Rev Food Sci 
Food Saf. 2010;9(6):635-654. Available from: 10.1111/j.1541-4337.2010.00131.x.

24. Pacheco-Palencia LA, Noratto G, Hingorani L, Talcott ST, Mertens-Talcott SU. Protective effects of standardized pomegranate (Punica granatum L.) polyphenolic extract in ultraviolet-irradiated human skin fibroblasts. J Agric Food Chem. 2008;56(18):8434-8441. Available from: 10.1021/jf8005307.

25. Rahim M, Saqib NU, Wahid F, Khan N, Alrawi LI. Analysis of toxic heavy metal content of the most widely consumed fruits. J Phys Sci. 2020;31(2):61-73. Available from: $10.21315 /$ jps2020.31.2.5.

26. Verma Y, Rana SVS. Assessment of cadmium, chromium, and copper levels in market fruit samples in Meerut, North India. Toxicol Environ Chem. 2014;96(10):15161522. Available from: $10.1080 / 02772248.2015 .1029735$.

27. Ibraheen LH, Abed SA. Accumulation detection of some heavy metals in some types of fruits in the local market of Al-Diwaniyah City, Iraq. Rasayan J Chem. 2017;10(2):339-343. Available from: 10.7324/RJC.2017.1021641.

28. FAO/WHO. Joint FAO/WHO food standers program, codes Aliment Arius commission contamination. vol. XV of 11. FAO, Roma CAC; 1984. p. 56.

29. Alagy B. Soil Pollution, Pesticide. vol. 1. and others, editor; 2015.

30. bin Nasser Eid Al-Subaie F, ibn Abd Al-Rahman M, bin Menem Shamshary H. Examining the canned food contamination with elements of heavy metals, nitrates and nitrites. Faculty of Agricultural and Food Sciences, King Faisal University; 2014. p. 89. 